\title{
A Prognostic Score for Brain Metastases of Non-small-cell Lung Cancer in the Era of Precision Medicine
}

\author{
Hua-Shai Hsu ${ }^{1,2,3}$. Sung-Lin $\mathrm{Hu}^{4}$. Chun-Ru Chien ${ }^{5,6,7}$
}

Received: 5 June 2019 / Accepted: 24 June 2019 / Published online: 29 June 2019

๑) Springer Science+Business Media, LLC, part of Springer Nature 2019

\section{To the Editor,}

We read the article by Rades et al. with great interest [1]. We agree that development of a prognostic score for brain metastases of non-small-cell lung cancer [BM-NSCLC] is essential. The cited authors appropriately incorporated features of systemic therapy into previous scoring systems when developing their system [WBRT-30-NSCLC], which is thus more precise than the earlier systems. This novel system will help clinicians who must engage in palliativecare decision-making.

However, we wish to emphasize the importance of the NSCLC molecular subtype in the present era of precision medicine; this has been incorporated into current treatment guidelines [2,3]. Several prognostic scoring systems for BM-NSCLC that include the molecular subtypes have been developed and validated (example: the "Lung-molGPA") [4, 5]. When treating BM-NSCLC patients with "druggable"

Hua-Shai Hsu and Sung-Lin Hu have contributed equally to this work.

\section{Chun-Ru Chien}

d16181@gmail.com

1 Hospice Palliative Medicine Unit, China Medical University Hospital, Taichung, Taiwan

2 Department of Family Medicine, China Medical University Hospital, Taichung, Taiwan

3 School of Medicine, China Medical University, Taichung, Taiwan

4 Department of Family Medicine, China Medical University Hsinchu Hospital, Hsinchu, Taiwan

5 Department of Radiation Oncology, China Medical University Hospital, Taichung, Taiwan

6 Department of Radiation Oncology, China Medical University Hsinchu Hospital, Hsinchu, Taiwan

7 School of Medicine, College of Medicine, China Medical University, North District, No.91 Hsueh-Shih Road, Taichung 40402, Taiwan mutations (such as drug-sensitive mutations in the epidermal growth factor receptor gene), further studies may be needed to compare the Lung-molGPA and the WBRT-30-NSCLC.

Acknowledgements We thanked "Textcheck Inc." for editorial assistance.

\section{Compliance with Ethical Standards}

Conflict of interest Dr. Chien received consulting fees, support for travel to a meeting, and payment for lectures from AstraZeneca in November 2018.

\section{References}

1. Rades D, Hansen HC, Schild SE, Janssen S (2019) A new diagnosis-specific survival score for patients to be irradiated for brain metastases from non-small cell lung cancer. Lung 197:321-326. https://doi.org/10.1007/s00408-019-00223-6

2. National Comprehensive Cancer Network Guidelines for NonSmall Cell Lung Cancer, version 4.2019 [free registration required]. https://www.nccn.org/professionals/physician_gls/pdf/ nscl.pdf. Accessed 3 June 2019

3. Planchard D, Popat S, Kerr K, Novello S, Smit EF, Faivre-Finn C, Mok TS, Reck M, Van Schil PE, Hellmann MD, Peters S (2019) Metastatic non-small cell lung cancer: ESMO Clinical Practice Guidelines for diagnosis, treatment and follow-up. Ann Oncol. https://doi.org/10.1093/annonc/mdy474

4. Sperduto PW, Yang TJ, Beal K, Pan H, Brown PD, Bangdiwala A, Shanley R, Yeh N, Gaspar LE, Braunstein S, Sneed P, Boyle J, Kirkpatrick JP, Mak KS, Shih HA, Engelman A, Roberge D, Arvold ND, Alexander B, Awad MM, Contessa J, Chiang V, Hardie J, Ma D, Lou E, Sperduto W, Mehta MP (2017) Estimating survival in patients with lung cancer and brain metastases: an update of the graded prognostic assessment for lung cancer using molecular markers (Lung-molGPA). JAMA Oncol 3:827-831. https://doi.org/10.1001/jamaoncol.2016.3834

5. Nieder C, Hintz M, Oehlke O, Bilger A, Grosu AL (2017) Validation of the graded prognostic assessment for lung cancer with brain metastases using molecular markers (lung-molGPA). Radiat Oncol 12:107. https://doi.org/10.1186/s13014-017-0844-6 